\title{
Pengaruh Substitusi Tepung Ikan dengan Hidrolisat Bulu Ayam terhadap Penampilan Produksi Broiler
}

\author{
E. Kusnadi \\ Fakultas Peternakan Universitas Andalas, Padang
}

\begin{abstract}
An experiment was conducted to evaluate the effect of substitution of fish meal with hydrolyzed feather-meal in diet on the performances of broiler of 2-6 weeks of age. The treatments consisted of five levels of hydrolyzed feather-meal: $0,4,8$, 12 and $16 \%$ in ration as $\mathrm{B} 0, \mathrm{~B} 4, \mathrm{~B} 8, \mathrm{~B} 12$ and $\mathrm{B} 16$ respectively. The data collected were analyzed with a completely randomized design of 5 X 4 (5 levels of hydrolyzed feather-meal and 4 replications) and continued with contrastorthogonal test when available. The results indicated that the level of hydrolyzed feather-meal significantly $(\mathrm{P}<0.05)$ decreased the feed consumption, but the abdominal fat content and caucus weight were not significantly affected. The body weight gain of A4 was found not significantly different with that of control (B0) (1407.5 vs. $1331.00 \mathrm{~g}$ ), but higher than that of B8 (1195.50), B12 (1118.75 g) and B16 (860.25 g).
\end{abstract}

Key words: fish meal, hydro zed feather meal, boiler nutrition

\section{Pendahuluan}

Tepung ikan adalah salah satu bahan pakan yang selain harganya mahal dan cenderung terus meningkat, juga ketersediaannya sangat bergantung kepada pengimpor tepung ikan tersebut. Oleh karenanya tidak mustahil jika harga ransum akan terus meningkat yang tentunya akan memberatkan baik pihak peternak maupun pihak konsumen asal ternak.

Bulu ayam merupakan salah satu produk sampingan peternakan ayam yang potensial untuk menggantikan tepung ikan serta belum banyak dimanfaatkan padahal bulu ayam memiliki kandungan protein yang tinggi yakni sekitar $81 \%$ (NRC, 1994) bahkan menurut Wang dan Parsons (1997) dapat mencapai 88,7 $\%$. Keunggulan lain dari bulu ayam yakni setiap $1 \mathrm{~kg}$ bulu ayam mengandung vitamin B 12 sebanyak 70-80 ug, vitamin B2 sebanyak 2 $\mathrm{mg}$, asam nikotinat sebanyak $20 \mathrm{mg}$, pantotenat sebanyak $9 \mathrm{mg}$ dan cholin sebanyak $1000 \mathrm{mg}$ (Vavak dan Fisherhova, 1990). Selain itu bulu ayam bila tidak segera diangkat akan menyebabkan pencemaran lingkungan yang dapat mendatangkan berbagai penyakit.

Laporan BPS (1999) menunjukkan bahwa stok ayam broiler pada perusahaan petenakan unggas pada akhir tahun 1999 di seluruh Indonesia tercatat sebanyak 12.392.930 ekor. Jumlah tersebut tidak termasuk populasi ayam broiler yang berasal dari peternak kecil yang jumlahnya jauh lebih banyak. Jika rata-rata bobot hidup $1,4 \mathrm{~kg}$ dengan persentase bobot bulu sebanyak $6 \%$, maka akan diperoleh bulu ayam sebanyak 1.041.006.12 kg. Oleh karena itu bulu ayam memiliki 
potensi yang besar sebagai bahan pakan dan berpotensi dalam menggantikan te-pung ikan dalam menyusun for-mulasi ransum.

Walaupun dilaporkan bulu ayam mengandung protein yang tinggi, namun kandungan keratinnya cukup tinggi pula sehingga kecernaan bulu ayam tersebut sangat rendah. Oleh karena itu bulu ayam tersebut diberi perlakuan lebih dahulu seperti hirolisis dan/atau dengan tekanan tinggi. Asam amino lisin dan metionin dalam bulu ayam nampaknya defisien, sehinga dalam penyusunan pakan ayam perlu penambahan kedua asam amino tersebut, sekaligus membantu sintesis karnitin yang diperlukan untuk metabolisme lemak. Dilaporkan bahwa, peningkatan tekanan selama hidrolisis tepung bulu nyata menurunkan kandungan sulfur, tetapi dapat meningkatkan kecernaan protein (Moritz dan Latshaw, 2001).

Penelitian ini bertujuan untuk mengevaluasi pengaruh penggunaan hidrolisat bulu ayam sebagai pengganti tepung ikan dalam ransum terhadap performan ayam broiler umur 2-6 minggu.

\section{Materi dan Metode}

Penelitian ini diawali dengan pengumpulan bulu ayam, pencucian, penjemuran dan hidrolisis menggunakan $\mathrm{HCl} 12 \%$ yang dilanjutkan dengan pemasakan denga panci "pressure cooker" serta pengeringan menggunakan oven. Sebelum bulu ayam digunakan, digiling dulu kemudian dianalisis kandungan proteinnya.

Pengamatan dilakukan 4 minggu dari umur 2 s/d 6 minggu menggunakan ayam broiler sebanyak 60 ekor. Secara acak ayam tersebut ditempatkan pada 20 sangkar kawat sehingga masing-masing sangkar dihuni sebanyak 3 ekor. Perlakuan pada penelitian ini meliputi 5 level pemberian bulu ayam yakni :

$\mathrm{B} 0=0 \%$ hidrolisat bulu ayam dengan tepung ikan $16 \%$.

B4 $=4 \%$ hidrolisat bulu ayam dengan tepung ikan $12 \%$.

B8 $=8 \%$ hidrolisat bulu ayam dengan tepung ikan $8 \%$.

B12 $=12 \%$ hidrolisat bulu ayam dengan tepung ikan $4 \%$ dan

$\mathrm{B} 16=16 \%$ hidrolisat bulu ayam dengan tepung ikan $0 \%$.

Semua ransum perlakuan dibuat iso kalori pada $3200 \mathrm{k} . \mathrm{kal} / \mathrm{kg}$ dan iso protein pada $21 \%$ yang sesuai bagi ayam umur 2 s/d 6 minggu (NRC, 1994). Sehubungan bulu ayam defisien dalam asam amino lisin dan metionin, maka pada ransum perlakuan yang diberi bulu ayam ditambah pula kedua asam amino tersebut sesuai tingkat kekurangannya.

Peubah yang diamati meliputi konsumsi ransum, pertambahan bobot badan, konversi ransum, kandungan lemak abdomen dan bobot sekum ; semuanya diukur pada akhir penelitian. Data yang dihasilkan dianalisis menggunakan Rancangan Acak Lengkap (RAL) 5 x 4 (5 perlakukan dan 4 ulangan), dengan uji lanjut menggunakan Uji Kontras Orthogonal.

\section{Hasil dan Pembahasan}

Pengaruh substitusi tepung ikan dengan hidrolisat bulu ayam terhadap konsumsi ransum, PBB dan 
konversi ransum dapat dilihat pada Tabel 1, sementara terhadap kandungan lemak abdomen dan bobot sekum ditampilkan pada Tabel 2.

Dari hasil diatas nampak bahwa peningkatan bulu ayam, nyata menurunkan konsumsi ransum. Namun pemberian bulu ayam sebanyak $4 \%$, penurunan konsumsi ransum justru diikuti dengan peningkatan PBB yakni dari 1331,00 menjadi 1407,50, walaupun secara statistik tidak menunjukkan perbedaan yang nyata. Hal tersebut didukung dengan turunnya konversi ransum dari 2,33 menjadi 2,08. Meningkatnya PBB pada pemberian bulu ayam sebanyak $4 \%$ atau paling tidak sama dengan kontrol, membuktikan bahwa tepung ikan dapat diganti dengan hidrolisat bulu ayam sebanyak $4 \%$ dari pemberian tepung ikan kontrol $16 \%$.

Rendahnya PBB yang dihasilkan pada pemberian hidrolisat bulu ayam pada level tinggi, menunjukkan mungkin belum baiknya tingkat hidrolisis pada bulu ayam tersebut, sehingga masih perlu diperbaiki. Hasil ini lebih rendah dari penelitian sebelumnya yang menunjukkan bahwa pemberian tepung bulu sebanyak $6 \%$ pada ayam broiler umur 5 minggu dengan penambahan metionin, lisin dan tritopan masingmasing $0,07,0,2$ dan $0,1 \%$, tidak menunjukkan perbedaan yang berarti dibandingkan tanpa pemberian tepung bulu (Cupo dan Cartwright, 1991).

Masih tingginya keratin pada bulu ayam yang belum terhidrolisis dengan sempurna, menyebabkan masih rendahnya tingkat absorpsi nutrisi dari bulu ayam tersebut. Penelitian Bielorai et al., (1983) menunjukkan bahwa absorpsi tepung bulu sekitar $50 \%$ lebih rendah dibandingkan bungkil kedelai yakni $85 \%$, yang diikuti dengan rendahnya absorpsi asam amino asam aspartat (37 \%), metionin (43\%), lisin (39\%) dan histidin $(22 \%)$.

\section{Daftar Pustaka}

Bielorai R, Hurduf Z, Losif B, Alumot E. 1983. Apparent amino acid absorption from feather meal by chicks. Br.J. Nutr. 49: 395-399.

Badan Pusat Statistik (BPS). 1999. Statistik Perusahaan Peternakan Unggas. Jakarta-Indonesia.

Cupo MA, Carlwright AL. 1991. The effect of feather meal on carcass composition and fat pad cellularity in broilers: Influence of the caloric: protein ratio of the diet. Poultry Scl 70: $153-159$.

Moritz JS, Latshaw JD. 2001. Indicators of nutritional value of hydrolized feather meal. Poultry Sci 80: $79-86$.

Nutritional Research Council. 1994. Nutrient Requirement of Poultry: 9 th, rev, ed National Academy Press, Washington DC.

Vavak J, Fisherova J, 1990. Keratine Waste. In: Nonconvencional feedstufts in nutrition of farm animals. Koloman Boda Edit. Elsevier, Amsterdam, Oxford, Inc. New York.

Voct.D, Voet JG, Pratt CW. 1999. Fundamentals of biochemistry, John Willey and Sons, Inc. New York. 
Wang X, Parsons CM. 1997. Effect hair meals. Poultry Sci 76: $491-$ of processing system on protein 496.

quality of feather meals and hog

Tabel 1. Rataan Konsumsi Ransum, PBB dan Konversi Ransum Ayam Broiler Umur 2 s/d 6 Minggu yang Diberi Hidrolisat Bulu Ayam Sebanyak 0 $\%$ (BO), $4 \%$ (B4), $8 \%$ (B8), $12 \%$ (B12) dan $16 \%$ (B16) sebagai Pengganti Tepung Ikan dalam Ransum.

\begin{tabular}{|l|r|r|r|r|r|}
\hline \multirow{2}{*}{ Peubah } & \multicolumn{5}{|c|}{ Level Hidrolisat Bulu Ayam } \\
\cline { 2 - 6 } & \multicolumn{1}{c|}{ B0 } & \multicolumn{1}{c|}{ B4 } & \multicolumn{1}{c|}{ B8 } & \multicolumn{1}{c|}{ B16 } \\
\hline $\begin{array}{l}\text { Konsumsi } \\
\text { Ransum (g) }\end{array}$ & $3100,50 \mathrm{~d}$ & $2927,50 \mathrm{c}$ & $2337,25 \mathrm{~b}$ & $2236,25 \mathrm{~b}$ & $1924,25 \mathrm{a}$ \\
& & & & \\
PBB (g) & $1331,00 \mathrm{c}$ & $1407,50 \mathrm{c}$ & $1195,50 \mathrm{~b}$ & $1118,75 \mathrm{~b}$ & $860,25 \mathrm{a}$ \\
$\begin{array}{l}\text { Konversi } \\
\text { Ransum }\end{array}$ & $2,33 \mathrm{~b}$ & $2,08 \mathrm{a}$ & $1,96 \mathrm{a}$ & $2,00 \mathrm{a}$ & $2,24 \mathrm{~b}$ \\
\hline
\end{tabular}

Keterangan: Huruf yang sama ke arah baris menunjukkan tidak berbeda nyata pada taraf 5\%

Tabel 2. Rataan bobot lemak abdomen dan sekum ayam broiler umur 2 s/d 6 minggu yang diberi hidrolisat bulu ayam sebanyak $0 \%$ (BO), $4 \%$ (B4), $8 \%$ (B8), $12 \%$ (B12) dan $16 \%$ (B16) sebagai pengganti tepung ikan ransum.

\begin{tabular}{|c|c|c|c|c|c|}
\hline \multirow{2}{*}{$\begin{array}{c}\text { Lemak pada } \\
\text { bagian: }\end{array}$} & \multicolumn{5}{|c|}{ Level Hidrolisat Bulu Ayam } \\
\cline { 2 - 6 } & $\mathrm{B} 0$ & $\mathrm{~B} 4$ & $\mathrm{~B} 8$ & $\mathrm{~B} 12$ & $\mathrm{~B} 16$ \\
\hline $\begin{array}{c}\text { Abdomen (g/kg BK) } \\
\text { Sekum (g/kg BK) }\end{array}$ & 21,04 & 21,02 & 18,60 & 19,05 & 20,13 \\
& 4,80 & 4,03 & 3,18 & 3,77 & 3,88 \\
\hline
\end{tabular}

Alamat korespondensi: Engkus Kusnadi

Jurusan Produksi Ternak, Fakultas Peternakan

Univrsitas Andalas, Kamus Limau Manis, Padang

Telp/Fax: 0751-71464, HP 0856780854

Artikel diterima: 27 Agustus 2005, disetujui: 25 Januari 2006 